\title{
Correction to: Venetoclax for Treating Chronic Lymphocytic Leukaemia: An Evidence Review Group Perspective of a NICE Single Technology Appraisal
}

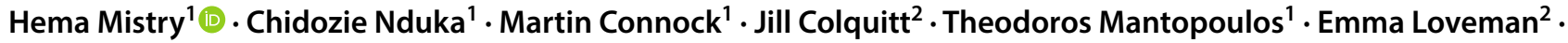 \\ Renata Walewska ${ }^{3}$. James Mason ${ }^{1}$
}

Published online: 19 February 2019

(c) The Author(s) 2019

\section{Correction to: PharmacoEconomics (2018) 36:399-406 https://doi.org/10.1007/s40273-017-0599-9}

The Open Access license, which previously read:

Open Access: This article is distributed under the terms of the Creative Commons Attribution-NonCommercial 4.0 International License (http://creativecommons.org/licenses/ by-nc/4.0/), which permits any noncommercial use, distribution, and reproduction in any medium, provided you give appropriate credit to the original author(s) and the source, provide a link to the Creative Commons license, and indicate if changes were made.

Should read:

Open Access: This article is distributed under the terms of the Creative Commons Attribution 4.0 International License (http://creativecommons.org/licenses/by/4.0/), which permits unrestricted use, distribution, and reproduction in any medium, provided you give appropriate credit to the original author(s) and the source, provide a link to the Creative Commons license, and indicate if changes were made.

The original article can be found online at https://doi.org/10.1007/ s40273-017-0599-9.

Hema Mistry

Hema.Mistry@warwick.ac.uk

1 Warwick Evidence, Warwick Medical School, University of Warwick, Gibbet Hill Road, Coventry CV4 7AL, UK

2 Effective Evidence LLP, 26 The Curve, Waterlooville, Hampshire PO8 9SE, UK

3 The Royal Bournemouth Hospital NHS Foundation Trust, Castle Lane East, Bournemouth BH7 7DW, UK
The original article was corrected.

Open Access This article is distributed under the terms of the Creative Commons Attribution 4.0 International License (http://creativeco mmons.org/licenses/by/4.0/), which permits unrestricted use, distribution, and reproduction in any medium, provided you give appropriate credit to the original author(s) and the source, provide a link to the Creative Commons license, and indicate if changes were made. 